\title{
The Coming Revolution of Peer Production and Revolution- ary Cooperatives. A Response to Michel Bauwens, Vasilis Kostakis and Stefan Meretz
}

\author{
Jakob Rigi
}

\author{
Central European University; rigij@ceu.hu
}

\begin{abstract}
This article agrees with Meretz (2014) that the peer producing cooperatives which are proposed by Bauwens \& Kostakis (2014) will become parts and parcels of the capitalist economy. Further, it argues that the so called Peer Production Licenses (PPL), originally designed by Dmitry Kleiner (2010), which is the basis of their proposal is a rent seeking instrument. Contra Bauwens \& Kostakis, it argues that, from the perspectives of both reform and revolution, GPL is profoundly anti-capitalist. The article critiques Meretz's understanding of exchange and reciprocity, on the one hand, and his underestimation of GPL's communist aspect, on the other. On the positive side, the article, explicating the communist nature of GPL-oriented peer production, speculates about the general contours of a society where peer production is the dominant mode of production. The technological basis of this society, the article suggests, will be digital copying and automation. Spatially, it will be based on localities that transcend the current division between the city and country, synthesising agriculture with industrial, affective and symbolic production. The rise of a globally unified revolutionary social struggle which adopts peer production as its platform is indispensible for the transformation of capitalism into such a society. A global network of revolutionary peer producing cooperatives which break with market and reduce their relations to it to an absolutely unavoidable necessary minimum can be a significant component of this social struggle. The building of these revolutionary cooperatives requires a massive exodus from the city to the country.
\end{abstract}

Keywords: Peer Production, Cooperatives, Revolutionary Struggle, Communism, Exodus From the City

Acknowledgement: I am grateful to Christian Fuchs for encouraging me to write this piece.

\section{Introduction}

When Christian Fuchs invited me to contribute to debate between Michel Bauwens \& Vasilis Kostakis, and Stefan Meretz on peer production and cooperatives, I happily accepted it. Indeed, a forthcoming article of mine under revision for publication in tripleC, had dealt with the focal problem of the debate. There, I critique Dmitry Kleiner's copyfarleft and his related Peer Production License (PPL) for being instruments of rent extraction by the designated peer producing cooperatives from workers who produce surplus-value elsewhere.

When I started writing the current contribution I did not expect that it would exceed a few pages. But, when I finished the conclusion, the text had already grown to 9000 words. This introduction summarizes and highlights my main arguments.

The first section presents concisely some of the main concepts of Marx`s critique of the political economy for two reasons. First, Bauwens \& Kostakis use concepts such as capital, value, profit and surplus-value in their commonplace usages. The presentation of Marx's concepts is meant to be a critique of this. Of course, although I think that Marx concepts are the only true ones, I do not mean to impose them on Bauwens \& Kostakis. I just invite them to offer their own precise definitions of these concepts and integrate them into a cohesive theory. Second, my critique of Bauwens \& Kostakis relies on Marx's concepts of value, surplus-value, profit, rent and the relation between individual capitals and the total social capital in the production and distribution of surplus-value.

The next section critiques Bauwens \& Kostakis. I argue, in tune with Meretz, though more elaborately, that to the extent that peer producing cooperatives take part in the market they 
will be assimilated into capitalism through logics of value, total social capital and rent. I also reject Bauwens \& Kostakis' claim that the GPL serves capitalism. First, I show that the GPL effectively abolishes knowledge rent. Second, I show that GPL-guided peer production offers an alternative to capitalism, and, therefore, can instigate and bolster anti-capitalist revolutionary struggles.

Then, I critique Meretz's understanding of reciprocity and his denial of the GPL's communist nature.The rest of the article does the following: it 1) explicates the communist nature of a GPL-oriented peer production; 2) speculatively describes the general contours of a society where peer production is the dominant mode of production; 3 ) demonstrates that social struggle will be instrumental for the transformation of capitalism into such a society; 4) argues that particular forms of revolutionary peer producing cooperatives which break with market, reducing their relation to it to an absolutely unavoidable minimum, can be a significant component of this social struggle; 5) presents a blueprint for such cooperatives; and 6) suggests that building of such cooperatives requires a massive exodus from the city to the country.

\section{A Few Essential Marxian Concepts}

\subsection{Value and Money}

A commodity is an entity that has both use value and exchange value. The exchange value of a commodity is the manifestation of an abstract value that is the form of congealed abstract labour in the commodity. Therefore, the magnitude of value is determined by the length of labour time. This labour time is the average socially necessary labour time. For example, if we have 100 different shoemakers who produce the same pair of shoes with different productivities, $T$ (the average social necessary labour time) is equal to the total sum of times of all individual shoemakers divided by $100(\mathrm{~T}=\mathrm{T} 1+\mathrm{T} 2+\ldots \mathrm{T} 100 / 100)^{1}$. Money is the physical body of value (congealed abstract labour), therefore, also its measure. That states issue money combined with the existence of various representations of money such as paper money and digital money creates the illusion that money is merely a form of convention. The conventions around and representations of money do not change the fact that money is the body of value that is the form of congealed labour time. To the contrary, these conventions and representations are viable due to the fact that money is the body of value that forms congealed labour time. Paper money and digital money have value to the extent that they are convertible to real money (value-congealed labour time). Otherwise they are not more than empty images. This is an important point to keep in mind because those who want to abolish capitalism but keep the market and money, have the false images that money as value is a result of conventions (Marx 1976, 125-163, 221- 227, 232-244).

\subsection{Surplus-value}

Labour power is a commodity and its use-value is labour. The distinction between labour power and labour is fundamental for the definition of surplus-value. The value of labour power is equal to the cost of its reproduction in a dual sense of the reproduction of the consumed energy by the worker during working and the reproduction of his body as the bodies of his children. The capitalist uses labour power for a length of time that is longer than the length of time that is necessary for the reproduction of the value of labour power. The difference is surplus-value (Marx 1976, chapters 6 \& 7).

\subsection{Capital and Its Accumulation}

Capital is money (value) invested in production in order to make surplus-value. Therefore, capital is not just a sum of money but a social relation in which capitalists extract surplus-

1 As I this concept of socially necessary labour time is central to my critique of Bauwens \& Kostakis' approach towards cooperatives I ask the reader to pay extra attention to it. 
value from workers (Marx 1976, chapters 4, $5 \& 6$ ). Accumulation of capital consists of the transformation of surplus-value into capital (Marx 1976, chapter 24).

\subsection{Profit}

Marx divided capital invested in the production of surplus-value into constant capital (C) (the value of means of production) and variable capital $(\mathrm{V})$ (the value of labour power), expressed in wages. This distinction was meant to emphasize that surplus-value was an extension (a surplus) over the value of labour power. And therefore surplus-value signified an exploitation of labour by capital, the rate of which was/is equal to surplus-value divided by variable capital $(S / V)$. From the point of view of the capitalist, such a distinction is useless. S/he considers surplus-value the fruit of the whole of his capital, undifferentiated into constant and variable forms. Surplus-value compared with the whole capital is metamorphosed into profit, and the rate of profit is $\mathrm{S} / \mathrm{C}+\mathrm{V}$ (Marx 1981, chapters $1 \& 2)$.

\subsection{The Total Social Capital, Individual Capitals, Competition, The Production Price and the Average Rate of Profit}

It appears that in the capitalist system each capitalist independently runs his own business and makes his own profit. A closer inspection, however, shows that each individual capital is an organic component, not only quantitatively but also qualitatively, of the total social capital. And its profit is a portion of the total surplus-value that the total social capital extracts from the total social labour (the working class as a whole). Hence, the origin of the profits of an individual capital is not merely the surplus-value it extracts from its own workers but the total surplus-value produced by all workers. In other words the capitalists as a totality exploit workers as a totality. Therefore the exploitation by a particular capitalist of his own workers is a component of this larger relation between labour and capital. This means that surplusvalue produced by individual capitals is first collected into a one great pool of surplus-value and then redistributed again among individual capitals. Collection and redistribution take place through competition between individual capitals. Capital leaves branches in which the rate of profit is lower and flows into branches where it is higher. As a result as the supplies of the products of the first branches decrease and those of the second branches increase, their prices respectively increase and decrease. This increases the rate of profits in the first branches and decreases those in the second ones. These outflows and inflows continue until a balancing point is reached. In this point each unit of individual capital receives the same amount of profit regardless of its investment site. In other words an average rate of profit which is equal to the total social surplus-value dived by the total social capital is shaped.

Now, the value of the commodity which is equal to capital + surplus-value $(C+V+S)$ is metamorphosed into its production price which is equal to capital + average profit $(C+V+P)$. $P$ is equal to the amount of individual capital multiplied by the average rate of profit. Therefore, commodities under the conditions of free competition are not sold for their values but production prices which can be higher, lower or equal to their values. In this way value is transferred from the commodities whose values are above their production prices to those whose production prices are above their values (Marx 1981, chapters $8 \& 9$ ).

\subsection{Rent}

The total social surplus-value is produced in the process of the production of commodities. These commodities can be material-solid goods such as shoes and sugar or immaterial service-commodities such as education, health care, etc. However, capitalists who directly extract surplus-value must share it with merchants, bankers, landowners, owners of knowledge and the state. The merchant receives an average profit in proportion to the size of the capital he deploys in the circulation sphere. The moneylender receives interest for lending his money to the investor. The landowner receives rent for leasing his land to him. The knowledge owner receives knowledge rent. And the state receives taxes for maintaining the conditions of the reproduction of capital. 
In this context we are concerned with rent. The most famous form of rent is ground rent. Unworked land has no value, but its use-value can be leased or sold, i.e. exchanged with money (value). The money that the owner of land receives for leasing it is rent, and when he sells the land the price is capitalised rent (rent divided by interest rate). Now, there are two other types of commodities whose prices are capitalized rent too, i.e. have prices but do not contain value. The first are those works of art that are perceived as being unique. The second is knowledge formally defined as information. A "unique" work of art has no value because it cannot be replicated. Therefore, it is the work of a singular work process and hence cannot be perceived as a product of abstract socially necessary labour. Its price (capitalized rent) is arbitrary, depending on the views of art critiques, the fluctuating bourgeoisie taste for art and speculations in the art markets. Knowledge-information has no value for the opposite reason. It can be infinitely reproduced at zero cost. Assume that a team of four engineers has spent 100 hours in writing software that can be digitally copied in 10 minutes. If the software is downloaded by 1000000 users the time incorporated in each copy will be 0.36 seconds which is negligible ${ }^{2}$. Therefore, the value of information tends towards zero. Yet, the holder of copyright of the software can demand a fee of 20 USD for each downloading earning an income of 20,000000 USD that is rent. To sum up, unworked land, unique works of art and knowledge information do not contain value but are sold for prices that are rent or capitalized rent. Now while unworked land, works of art and information are not value, the money they are exchanged is value. This value is either part of the total social surplus-value produced by the working class or part of the value of labour power when the purchaser or renter is a worker. In both cases the origin of value is the working class.

There is a major difference between the ground rent and the unique work of art rent, on the one hand, and the information rent, on the other. The former have a natural-material basis in that the object of rent is naturally-materially scarce/exclusive. The ground rent and the unique work of art rent arise out of ownership of rare objects. A piece of information is not unique, on contrary, it can be reproduced infinitely. Therefore, it can only yield rent through intellectual property that obliges the user to pay a fee to the holder (Marx 1981, part 6).

\section{A Critique of Bauwens \& Kostakis}

I start this critique with summarizing their views. The two authors claim that we have two types of emerging movements: the cooperative movement and worker-owned enterprises; and peer production. But each has fatal shortcomings of its own. The shortcomings of cooperative movement are: a) they are not always willing to accept new partners, and share profits and benefits with others; and b) they are implicated in the capitalist forms of intellectual property, competition and monopoly pricing, etc. These undermine cooperative movement's long term goals.

The peer production shortcomings are two: first, the apparently communist license of the GPL serves the interests of capital by helping capitalists to capture the value which is produced by peer production; second, as a proto-mode of production peer production has not its own base of reproduction as those who contribute to it are depended on capitalism for their livelihood.

The problems of both movements will be solved if they merge into peer-to-peer producing cooperatives on the basis of a Peer Production License (PPL), a concept formulated by Dmitry Kleiner in 2010. The PPL advantage over GPL is that it generates revenues for cooperatives by demanding direct reciprocity from capital. This helps peer-producing cooperatives to keep profits and surplus-values they produce for themselves.

In a certain point of their expansion these cooperatives will displace capitalism as the dominant mode of production.

I commend Bauwens \& Kostakis for their activist approach and their good intensions to develop an alternative to capitalism and establish an ethical economy. Unfortunately, however, their approach not only fails to achieve these goals, but perpetuates capitalism. On the

2 I ignore the downloading time, because this can be, and is usually, done by the user. 
most general level this is evident from their attitude towards value, capital, surplus-value, and profit. In their usage these categories and their phenomenal referents appear as neutral. It is implied in both their project and in their arguments that both capitalists and workers can harness these phenomena for opposing purposes: capitalist can use them for the accumulation of capital and peer producing cooperatives for the expansions of the commons. So we have a weird claim that cooperatives keep the profit and surplus-value within themselves and generate a stream of monetary income from capitalism to build capital for commons. As we showed above surplus-value, profit and capital do not merely refer as sum of monies but also and mainly as social relations the essence of which is the exploitation of labour by capital. You cannot keep these categories without perpetuating the capitalist exploitation. Hence, Bauwens \& Kostakis` project perpetuates capitalism by keeping these categories. Their capital-promoting approach is more concretely evident in their design for peer producing cooperatives and their preference for PPL over GPL.

Bauwens \& Kostakis proposed peer-producing cooperatives make money. But how? Simply by selling things they produce. The things they produce can be one of three categories: material goods and immaterial services that have values (these goods and services are subjected to a relative law of natural scarcity); peer produced "unique" works of art; or knowledge information. Let us tackle each in turn.

For making a profit and accumulating capital for commons a peer-producing cooperative cannot give away for free its commodities that have value to other peer producing communities. It must sell its commodities for market prices to the members of other peer producing cooperatives as to anyone else. Otherwise, it will sooner or later be outcompeted by capitalist enterprises that produce similar commodities and will go bankrupt. Such a cooperative as Meretz nicely shows is by necessity doomed to bend to external pressures of competition and obey the rules of the market. This will necessarily force it to take part in the capitalist mechanism of exploitation. As I will show below it must either produce surplus-value for its competitors or suck surplus out from them. In the first case its members are exploited in the capitalist way by producing surplus-value for others, in the second case they themselves become a collective capitalist by extracting surplus-value from the workers of other cooperatives and workers of capitalists. This happens on two levels of the formation of the value of a commodity and its price of production. Assume that a given cooperative produces a certain type of bread for the market. The same commodity is also produced by 9 capitalist companies. Assume further that the labour time spent by the cooperative on production of bread is $\mathrm{T} 1$, and those by capitalist companies are respectively $T 2, T 3, \ldots$ and $T 10$. The average social necessary labour time for the production of bread is $T$. It follows that $T$ is equal to $\mathrm{T} 1+\mathrm{T} 2+\ldots+\mathrm{T} 10 / 10$. Now, if $\mathrm{T} 1$ is larger than $\mathrm{T}$, i.e. the productivity of the cooperative is below the socially necessary productivity, the capitalist producers collectively extract the labour time of T1-T from it. In other words the bread capitalists collectively exploit the workers of the cooperative. If $\mathrm{T} 1$ is smaller than $\mathrm{T}$, due that the cooperative's productivity being higher than the average, the cooperative extracts the labour time T-T1 from the workers who work in the capitalist sector, i.e. it exploits them. In either case the cooperative takes part in an exploitation that is by nature capitalistic.

The same happens again if we consider the relation of our cooperative not only with other producers of bread, but with the capitalist economy as a whole. If the average capital that is invested in the production of a unit of this type of bread is $c$, the production price of this bread will be equal to $c+$ average profit per unit which is equal to $c+c$ multiplied by the average rate of profit that is in its turn equal to $c+c$ multiplied by the total social surplus-value divided by total social capital. Now, if the value of bread is above its production price other sectors of capital whose values are below their production prices extract a value from the producers of this type of bread. This value is equal to the difference between its value and its production price. If, on contrary, the value of bread is below its production price, then the producers of bread extract a value that is equal to the difference between the price of production and the value from other capitalists. In both cases the collective labour of the cooperative is involved in transfers of value, because, its labour takes part in the formation of average socially necessary labour time that determines the value of the bread. 
To sum up the cooperative is implicated in the capitalist mechanism of exploitation either as an exploited or exploiting party in the both processes of the formation of values and that of the production prices of the commodities they produce. A single commodity is a social interface (relation) in a double sense. On the one hand as a value bearing entity it is an interface between all labour that produces that type of commodity. And on the other, as a price bearing entity it is an interface between all constituent elements of the total social capital, i.e. the capitalist economy as a whole. No magic of cooperation can change these realities. The only way for cooperatives to break with the logic of capital is to break with the market, i.e. not to produce commodities. Therefore, Bauwens \& Kostakis by keeping the categories of the commodity (commons once sold to a capitalist becomes a commodity), market, value, surplus-value, profit and capital envisage a form of cooperatives that is essentially capitalist.

Bringing the PPL into the picture does change these facts because the PPL as a license only relates to intellectual property not property in general. If we take the bread example, the PPL only applies to knowledge about the production of bread. This knowledge can be either an innovation that enhances the productivity and thereby cheapens the production of bread or something that ads a new quality (taste/flavour) to the bread which increases the demand for it and hence its price.

Now, a Bauwens \& Kostakis' version of the peer-producing cooperative-bakery publishes this knowledge under the PPL. Everyone is entitled to use this knowledge for free, including those capitalists who improve this knowledge and publish the improvement under the PPL. Only those capitalists who do not improve this knowledge or improve it but are not willing to publish the improvement must pay a fee. The publishing of knowledge by the cooperative is incompatible with the production of bread as a commodity because it undermines the competiveness of the cooperative. But to the extent that capitalists are paying a fee to the cooperative for using the knowledge this fee is a rent that is a part of the surplus-value produced by the total social labour exploited by the total social capital. Hence, the cooperative exploits other workers by extracting surplus-value from them. We will return to this below after having dealt with the sale of unique works of art by cooperatives.

The uniqueness of a special work of art is something subjective determined by a combination of views of art critics, the fluctuating bourgeoisie's tastes for art and speculation. Artistic works which are treated differently from their reproductions are sold for rents that are part of the total surplus-value produced by the working class. Therefore to the extent that a peerproducing community sells these types of art to the exploiting classes it also extracts surplusvalue from the working class.

The third form of the commodity that a peer-producing community can sell is information/knowledge. It includes everything that can be digitised, digitally reproduced and electronically transported. These commodities do not contain value and their prices are rent. Therefore, the capitalist forms of intellectual property (copyright, patent and trade mark) are means of the extraction of rent. The PPL, a form of intellectual property, has two faces. In relation to other cooperatives, the general public and those capitalists who contribute to the commons, the PPL defines knowledge as commons. On the other hand in relation to capitalists who do not contribute to the commons, the PPL defines knowledge as a commodity. This means that the cooperatives extract rents from such capitalists that are portions of the total surplus-value produced by the total working class. This makes cooperatives' workers the exploiters of other workers, splitting them in antagonistic camps. Therefore, Bauwens \& Kostakis' claim that the PPL is more beneficial to the commons than the GPL is misleading. Below, I compare the PPL and the GPL from the points of view of commons and capital.

\section{The GPL, the PPL, the Commons and Capital}

Stallman formulated the GPL as a means of resistance to commoditization of the commons of software, on the one hand, and also as the means of expansion of these commons, which he called Free Software, on the other. Therefore, the GPL is the opposite of the conventional copyright that protects the proprietary software and therefore, its main characteristics are more clearly pronounced when the GPL is compared with conventional copyright. The con- 
ventional copyright and the proprietary software are the means of the extraction of rent. The GPL abolishes software rent. The GPL does not prohibit the sale of software, which means that someone can sell it and make a rent. But this possibility is counterveiled by the fact the GPL also permits the free online distribution of software. Therefore, It is unlikely that someone will pay for software that is published online. The PPL, on the other hand, like conventional licenses keeps the rent, though only in relation to a certain type of capitalists. It is important to point here to a major difference between Kleiner's version of the PPL and that of Bauwens \& Kostakis. Kleiner's license obliges all capitalists who use the work to pay a fee, Bauwens \& Kostakis' version only obliges those capitalists who do not contribute back to the commons to pay the fee.

Kleiner, Bauwens \& Kostakis justify this keeping of rent by arguing that the GPL allows the capitalists to have a free ride on the commons. The evidence they offer is that big companies such as IBM use Linux to make profit. As I will show below they take a deceptive appearance for reality.

First of all, let me remind the reader that software/knowledge/information whether proprietary or free has no value. Its value is zero. With this in mind, I argue that those capitalist who produce knowledge to be exchanged for rent cannot make extra profit by using free software. The reason is the Copyleft clause requires that all components of any product that contains at least one element under the GPL must also be released under the GPL. In this sense the GPL prevents the commoditization of its derivatives and their exchange for rent. It also means that no one can combine knowledge under the GPL with proprietary knowledge unless the proprietary knowledge has already been transformed into commons under GPL. As a matter fact some major companies including IBM transformed their proprietary software into commons in order to be able to use Linux. This means that the GPL indeed extracts commons from capitalism.

The so-called Open Source License (OSL) which was invented by the business-friendly elements within the Free Software Movement permits the combination of the derivatives of knowledge under the GPL with proprietary knowledge and requests that only the GPL derivatives must be released under the GPL, while others can remain proprietary. In this way the totality of the product remains proprietary and is sold for a price that is rent. But the OSL was invented to subvert GPL and was vehemently opposed by Stallman. Indeed, the OSL, and the PPL share the rent seeking aspect with propriety licenses.

Only capitalists who produce commodities that have value can make extra profits by using free software. Assume that we have a capitalist farmer who has borrowed his capital from a bank, and grows wheat in a land he has rented from a landowner. He also needs software to operate his machines and for other purposes. If the amount of his capital is $\mathrm{C}$, and the average rate of profit is $\mathrm{K}$, his profit will be $\mathrm{K}^{*} \mathrm{C}$, and the production price of his product will be $\mathrm{C}$ $(k+l)$. Now he must share his profit with the following agents: the merchant who sell his wheat; the bank who has lent him money; the landowner; and the owner of the software. He must also pay taxes. So, all in all the profit is divided into six components: the profit of investors; the profit of merchants; the interest of banks; the ground rent; the knowledge/software rent; and taxes. If the investor uses Free Software, he does not pay software rent and thereby his own profit becomes larger. This argument is true of both individual capitals and the total social capital.

To the extent that the value producing capitalist does not pay knowledge rent his own profit increases. But this does not change a penny the magnitude of the total social value, or total social surplus-value that is equal to the profit of the total social capital.

It is in the benefit of workers and society as a whole that after taxes are paid the rest of the profit remains in the hands of the producing capitalist and is not shared with the merchants, bankers, landlords, and knowledge "lords". Why? The answer is that workers and society can claim this additional profit. Workers can demand (of course through struggle) higher wages and/or the reduction of the labour day equivalent to the surplus labour time which produces that part of surplus-value that is metamorphosed into commercial profit, interest and rent. The state can also increase taxes using the additional revenues for the welfare of population. That the most sensible ideologists/theorists of industrial capitalism such as David Ricardo 
and John Maynard Keynes vehemently condemned rent and interest indicates that from the point of view of industrial capitalism the rentier and financiers are parasites. The working class shares this view. However, after the abolishing of rent and interest capitalism still remains capitalism, even if a better capitalism. The working class cannot stop at this, it must abolish capitalism altogether.

The historical significance of the GPL's anti-rent aspect can be best understood if we put it in the context of the neoliberal era. Stallman invented the GPL in 1984, at a time when neoliberalism was underway. Despite this contemporaneity, the GPL was not a component of neoliberalism but a negation of it. Enclosures of the commons of land, urban commons, and the commons of knowledge, as mechanisms of "accumulation by dispossession" (Harvey 2004) have been a main pillar of neoliberalism. The financialisation of the world economy has been its other pillar. The rents resulting from enclosures of the commons functioned as a major basis for financialization and speculation (Harvey 1982, 2012; Teixeira and Rotta 2012; Rigi and Prey Forthcoming). Therefore neo-liberalism can be described as an alliance between finance capital and rent seeking interests. The close link between financialisation and rent was particularly exposed in the crisis 2007-onwards by the fact that the stagnation of the housing market triggered a global financial meltdown. Therefore, the struggle for the simultaneous abolishing of rent and interest should have been and still is a major pillar of anti-neoliberal struggle. The following must be the slogans of an anti-neoliberal campaign: AHOLISH RENT; ABOLISH INTEREST; TRANSFORM LAND INTO COMMONS; RECLAIM THE URBAN COMMONS; TRANSFORM KNOWLEDGE INTO COMMONS; REDUCE LABOUR TIME; INCREASE WAGES; INCREASE TAXES ON CAPITALISTS; A BASIC INCOME FOR ALL; FREE EDUCATION; AND FREE HEALTH CARE.

The interests of a broad spectrum of rural and urban populations of various parts of the globe on the one hand, and different social movements on the other, converge in these slogans. Although these are reforms, the struggles for them can acquire a revolutionary character if: 1) they are integrated into a unified struggle against the total global social capital; 2) they adopt peer-production as an alternative to capitalism. I will return to these points below. Here, it suffices to emphasize that Stallman, without perhaps knowing it or using a Marxian language, mounted a frontal resistance against the neoliberal surging greed for knowledge rent and the enclosures of the commons of knowledge from the very start of the neoliberal attack. The GPL was and remains a platform for abolishing rent and the expansion of the commons. In this respect the GPL is even more radical than movements of the "Right to the City" and peasants' resistance against the enclosure of urban and rural commons. The reason is that the GPL is not merely an instrument of resistance, but also offers and produces an alternative to the commodity, namely commons. It is a productive negation.

To sum up Bauwens \& Kostakis' peer-producing cooperatives will be exploited by capitalists or will exploit other workers to the extent that they sell commodities that have value. They will exploit other workers to the extent that they exchange valueless knowledge with capitalists for rent. The GPL is far more commons-promoting than the PPL. First, the GPL abolishes rent, whereas the PPL in line with the OSL (Open Source License) perpetuates it. Second, the GPL demands that proprietary knowledge can only be combined with knowledge under the GPL if it is transformed into commons. Bauwens \& Kostakis' version of the PPL has dropped this demand, because, it charges those capitalists who are using commons but are not able or willing to contribute to it. In practice this means that when capitalists pay for the use of commons under the PPL they can transform its derivatives into proprietary knowledge. In other words the PPL permits the privatisation of the commons in exchange for rent.

The flaws of Bauwens \& Kostakis' approach apart, the idea of peer-producing cooperatives as a platform for launching peer-production is appealing. But these cooperatives' main direction should be to work against the market and money and break with them. In the final section of this essay I will introduce my own proposal for this. Before that, however I make some critical remarks on Stefan Meretz's rejoinder to Bauwens \& Kostakis. 


\section{A Critique of Stefan Meretz's Rejoinder to Bauwens \& Kostakis}

Meretz's critique of Bauwens \& Kostakis includes the following elements:

* The GPL is not communist, because, it is exclusionary. It is not capitalist, either, because, it promotes the commons and not the commodity.

The GPL promotes reciprocity, while the PPL promotes exchange, which has a different logic. Bauwens \& Kostakis simply confuse exchange with reciprocity. By promoting exchange the PPL is a means of the commoditization of the commons.

* Cooperative-owned enterprises, even when helped by the PPL, remain companies not commons. Therefore, in order to be profitable they must compete with other similar enterprises whether cooperatives or capitalist enterprises. They must either adopt the logic of capital or will go bankrupt.

* Bauwens \& Kostakis' project is not a road towards subversion of capitalism and building an alternative economy but a way to access capitalism.

As my arguments in the previous sections show I agree with most of Meretz's criticism of Bauwens \& Kostakis. However, I find two problems in his rejoinder. His distinction between exchange and reciprocity is not helpful. Second, he does not grasp the GPL's communist nature and its revolutionary-transformative historical potentials.

Briefly, exchange is reciprocity and reciprocity is exchange. Even, the exchange of money for commodity is reciprocity. You give money, you receive a commodity. Somehow Meretz falls into Bauwens \& Kostakis' trap who claim that the GPL involves indirect reciprocity while the PPL requires direct reciprocity between peer-producing cooperatives and capitalist enterprises which do not contribute back to the commons. While Meretz correctly exposes what Bauwens \& Kostalis call "direct reciprocity" as commodity exchange, he mistakenly calls it exchange, while it is more correct to call it commodity exchange. Exchange also can be applied to the gift exchange which is also based on a quantitative logic of equivalence but is different from commodity exchange in that in the former the goal of exchange is to create and maintain personal relations and political alliances while the latter's goal is economic.

Marshall Sahlins (1974) in his Stone Age Economics distinguished between three types of reciprocity: negative (commodity exchange), balanced (gift exchange) and general reciprocity. In the first, while theoretically exchange is based on the logic of equivalence the parties bargain, the seller tries to sell more expensively and the buyer tries to buy cheaper. One party tries to win at the expense of the other. In the second, bargaining is ruled out and the logic of equivalence must be strictly observed, at least in the classical gift exchange between tribes' chiefs. If you reciprocate a smaller gift to your partner you may offend him. You may also offend your partner if you give him such a big gift that he cannot afford to reciprocate. The logic of equivalence is a very subtle means of political balance/alliance. Furthermore, within such alliances the giving, receiving and reciprocating gift are obligations. The failure to fulfill any of them may result in dissolution of the alliance, or even worse, in conflict and war (Mauss 1925/1954). In the general reciprocity there is no logic of equivalence, you give without expecting to receive something back directly.

Now the GPL stipulated reciprocity does not fit into any of these forms. Because unlike Sahlins' general reciprocity the giver always receives back something larger (the whole improved software $=$ the sum of all contributions) of what $s /$ he gives (her/his contribution). On the other hand the receiver is not obliged to contribute, i.e. s/he receives the sum of all contributions without being obliged to contribute as long as s/he does not publish the derivative. We may call this a communist form of reciprocity.

Of course, Meretz is correct that the GPL as a license is a contract, a juridical form, a social rule and not immediately reciprocity. But this contract stipulates a universal reciprocity, and in this sense it is communistic. Communism is nothing but universal reciprocity. Knowledge under the GPL is a universal commons, another feature of communism. The GPL stipulated universal reciprocity is free from all obligations, except one. If you publish any derivative of GPL stipulated universal commons you must also publish it as universal commons. Meretz finds this a form of exclusion and therefore disqualifies GPL stipulated universal reciprocity as being a form of communism. Inclusion always presupposes exclusion. Whether in 
a fully-fledged communist society the dialectic of inclusion/exclusion will be superseded is a question of the future. But under the current circumstances the protection and growth of universal commons/universal reciprocity require the exclusion of those who try to privatise it. The GPL, indeed, distinguishes between private use and privatisation, permitting the former and prohibiting the latter.

\section{The GPL-Peer Production and Communism}

A related deficiency of the GPL, which Meretz also notes, as of any other form of intellectual property, is that its enforcement relies on the state. Of course, in the advanced communism in Marx's description state and rights, including intellectual property rights, belong to the past. The fact that today universal reciprocity/communism needs to resort to bourgeois jurisdiction in order to emerge, grow and protect itself is a sign that this communism does not stands on its ground yet. It consists of some scattered islands in the seas of capital and the state. Its proper ground can only be established through a social revolution that abolishes capital, the state and the social division of labour. The significance of GPL-guided peer-production for this social revolution is that it, for the first time in history, presents a communist mode of production, even if in its embryonic phase, in practice.

It is important to stress that the GPL is in the first place about production not distribution. The reason is because knowledge can mainly be used as a means of production of both new knowledge and non-knowledge products. The productive orientation of GPL is particularly evident in the requirement that technological know-how should be documented and published alongside the product. Therefore, the GPL inherently results in cooperation. Assume that programmer $\mathrm{X} 1$ writes the code $\mathrm{y} 1$, and $\mathrm{X} 2$ using $\mathrm{y} 1$, produces $\mathrm{y} 2, \mathrm{X} 3$ uses $\mathrm{y} 2$ to produce $y 3$, and this process continues till $X 100$ who produces $y 100$ by using $y 99$. Then, $y 100$ is the product of cooperation between $\mathrm{X} 1, \mathrm{X} 2, \ldots$ and $\mathrm{X} 100$. This is communism in the realm of cooperation/production supplemented with communism in the realm of distribution by the fact that the GPL makes y1, y2... and y100 universal commons. GPL enabled cooperation anticipated that of Linux's. The major difference between them is that in Linux due to the mediation of net the cooperation of peers is simultaneous, interactive and occurs in real time while prior to invention of the net this cooperation was sequential. As I have argued elsewhere (Rigi 2013), this form of cooperation subverts both social and technical capitalist divisions of labour. Communism is nothing but realization of individual potentials through voluntary participation in social production and making the product available to all members of society regardless of their contributions. And this is exactly the description of GPL enabled peer production.

\section{Peer Production as the Dominant Mode of Production}

Now, one can raise the following legitimate questions:

How can the GPL/Linux model be applied to material production?

What will be the general contours of a society in which both intellectual and material production are taking place through peer-production?

In material peer-production two factors are prominent: territorialisation and automation. Linux's production process is truly de-territorialized as a contributor can be on the any point of the planet where s/he can access a computer. Later, s/he can post her/his contribution through accessing the Internet. The material production cannot ontologically be mobile. It must necessarily be located in one or several places. Today multinationals produce different components of certain commodities in different parts of words. Then, these companies themselves or buyers assemble components into finished products in certain places. This form of the globalization of production due to transportation costs and ecological problems does not fit peer-production. The production site must be in the proximity of the consumption site. Peer production must reduce the transportation costs to the minimum of the costs of import of raw materials and food that cannot be produced locally. The territorial principle of peer production requires a new spatial revolution that negates the current division between the country and the city. As peer-producing communities must grow their own food their production- 
consumption units acquire an agricultural aspect. On the other hand these units are also the sites of production-consumption of all types of symbolic/artistic forms, and goods and services that make the cities today. Peer production is a model for green reindustrialization, urbanization of the country, and ruralisation of the city. Peer-producing communities are organically rural-urban. Their size can vary depending on the fertility of land but the maximum population should not exceed say 200000 . These new urban-rural spaces can be created through two paths: 1) a huge exodus of the population from cities to rural areas where food can be grown; 2) a transformation of major parts of current cities into agricultural land.

Although small in size these spaces are not provincial for two reasons. First, they are sites of creativity and the production of cultural forms in all their richness and variety; second, they are globally connected to similar spaces through the Internet, roads, railways, the air and the sea.

Material production is overwhelmingly automated in these spaces through the uses of robots, CNC machines, 3D Printers, etc. As machines can reproduce themselves, human contribution to production mainly consists of science, design and software. Science, design and software as form of knowledge are globally produced according to the Linux model. The conclusion is that a combination of a Linux mode of cooperation with automation will generalize peer production to all branches of production. Three important caveats are in order here. First, technologically, it might be impossible to automate all operations that are required for certain types of material production. Second, automation does not exclude the revival of crafts as a form of artistic activity. To the contrary it may create a new basis for such a revival by providing human beings a lot of free time. Third, as care and education cannot be automated they require their own specific modes of peer cooperation.

As the material production is managed by machines human beings are mainly involved in two types of productive activity: symbolic activity (producing knowledge and arts; I include crafts in this form of activity too) and care for humans and nature ( $I$ include education in care).

A necessary precondition for the existence of a peer-producing community as described above is the removal of private property over land and its transformation into commons. The land as the source of food must be a common. Land from another point of view needs to become a common too. As machines reproduce themselves, the main factors of material production will be knowledge and raw material. If knowledge is universal commons the second must also become a commons. Related to this the strategic raw materials and energy must become universal commons of humanity.

\section{The Necessity of the Social Revolution and the Significance of Struggle}

As we know land is today privatized and landed property is defended by the violence of the state. Hence, the transformation of land back into commons requires social revolutions that abolish the private ownership over land. This revolution must overcome the state and its violence and abolish them. In addition to land the global infrastructures of communication and transportation must also become a common. As these are also privately owned today their transformation into commons provides another reason for social revolutions.

In short GPL-production has put a new epoch of social revolutions on the historical agenda.

Thus, in spite of its elegant simplicity, the GPL inspires us to engage in fundamental struggles against capitalism both in the realms of reform and revolution. In the realm of reform it inspires us to demand the abolishing of rent and interest, a basic income, the increase of wages, the shortening of labour time, and reclaiming the commons of land, knowledge and the city. In terms of revolution it inspires us to abolish capital and the state and to replace them with peer-producing communities.

The instrument of materializing these goals is a permanent peer-produced political revolutionary organisation-movement that makes the materialization of the above its main platform. The fact that since 1999 the major instances of political protests have been peer-produced (Maeckelbergh 2009) indicates the existence of real forces for building this organisation. 
These protest movements, however, had two major interrelated weaknesses. The first was that they were merely negative movements. They were reactions to meetings of the IMF, the WTO, the G8, - and since 2007 to the economic crisis. This weakness was highly evident in the so-called Occupy Wall Street movement that took a pride in not having positive demands, indeed, a pathetic attitude. They presented their very weakness and disorientation as strengths. The result was the endless chatting among activists. Of course, I do not mean to belittle the pedagogical value of OWS's rehearsal of the peer production of politics. But a real peer production of politics cannot be achieved unless it is matched by a platform for immediate reforms and strategic revolutionary changes in the realms of production and distribution. Instead of occupying a park and wasting time on creating a theatrical peer-to-peer democracy, they should have occupied lands, buildings, major industrial sites, telecommunication centres and reorganized production and distribution on the basis of peer production. Instead of waiting for the police to come to repress and disperse them, they should have armed themselves, abolished the police and peer-produced the necessary security for citizens and with citizens. This indeed happened in Cairo in the stage when Mubark's thugs tried to intimidate people in neighbourhoods by resorting to looting.

The second weakness that stems from the first one has been the lack of permanence and continuity. These movements surge when something happens in the camp of capital, whether a meeting of its representatives, or something more drastic such as the recent crisis. And then they recede. A real revolutionary movement, although it must always respond to what is happening in the camp of the enemy, must be self-grounded and self-determined. It can only become self-grounded if it has its own platform for change. It needs not only to proclaim that "another world is possible" but also to draw the contours of this other world as much as it is possible. It must also put forward immediate demands that address the common interests of broadest sections of the population (to abolish rent is a good example of such demands) on the one hand and the particular interests of each section on the other. Self-grounded movements need platforms that combine the ultimate goal of peer-to-peer revolution with urgent immediate demands. With these platforms at hand it becomes necessary to peer-produce a global network of revolutionary organizations that organize social struggle on the model of peer production and work continuously to advance these platforms. Revolutionary cooperatives described below can be an important component of such organizations.

\section{Revolutionary Peer Producing Cooperatives}

The blueprint below is only meant to be a thought experiment and at best a " kernel" that can be fully modified and developed in various directions. This kernel has two aspects: These cooperatives must be revolutionary, second, they must break with the market as much as they can. They must be organized as a network of cooperatives scattered around the world, connected with each other through the peer-produced revolutionary movements that aim to replace capitalism with peer production. Each cooperative produces its own food on its commons of land. This commons in contrast to the commons of knowledge is restricted in the sense that it belongs to its members. The cooperative must be open to admit new members. The ceiling for the population of cooperatives is the number of people that the land can sufficiently feed.

The cooperative peer produces the necessary care and education for its members where good and free public care and education are not available. As a rule, however, the revolutionary movements must try to force states to provide these services, funded by taxes paid by capitalists.

The cooperative is involved in the global production of software, design, and all symbolic items through peer production under the GPL. The cooperative automates the material production to its ultimate level. It will produce and use automated machines with highest generic capacities such as CNC machines and 3D printers that can process the broadest range of raw materials and form them into broadest ranges of shapes.

In this way the cooperative produces most of the material products, including the machines that it needs for itself. There are items such as certain raw material, or certain type of 
food/ medicine, or certain form of energy that the cooperative itself cannot produce. Therefore these items must be procured from outside.

A partial solution to this problem is that all cooperatives around the world make a common pool of their surplus material products that is available to all of them. Or involve in mutual bartering, depending on scarcity of certain products.

Therefore, the cooperative movement must, to the extent that is possible, try to create its own transportation and communication networks/infrastructure.

Yet, a cooperative may still need cash for purchasing something that is not available in the common pool, or otherwise the cost of its transportation from the commons that does not need it to the commons that needs it is much higher than its price in the local market. For earning this cashes the cooperative can sell products or services in the market.

In this way peer producing cooperatives are partially implicated in the capitalist regime of value and its exploitative mechanism. But they can minimise the corrupting effects of this exchange in two ways: 1 ) by reducing this contact with the market to its absolute necessary minimum; 2) by keeping the earned cash in a special fund which is used for the purchase from the market. Money should have no role in the distribution of goods and services between the members of a cooperative. Further, the members should not have their own money, the cost of their travels, accommodation and food purchased in the market should be funded by the cooperative.

The existence and growth of such cooperatives that on the one hand break with capitalism, and on the other still remain dependent on it, are hazardous, unstable, ridden with problems and riven by contradictions. They can only exist, grow and survive as components of a broader revolutionary peer produced movement that aims at replacing capitalism with peer production.

The expansion of such cooperatives requires an exodus from the cities to the countryside and ushers a new struggle over land ${ }^{3}$. This requires the seizure of land from landowners and its transformation into commons. Therefore, at this stage immediate struggle over land is the most vital issue for building these cooperatives.

\section{Conclusions}

I commended Bauwens \& Kostakis activist approach but showed that their model of peerproducing cooperatives makes these cooperatives similar to capitalist rent and profit making enterprises. I also explicated dual interconnected potentials of the GPL/peer production for major reforms, on the one hand, and for revolution on the other. I argued that in terms of reform the ethos of the GPL instigates the abolishing of rent and interest which can put on the agenda reclaiming the commons, and demanding basic income, increases of wages, reductions of labour time, etc. In term of revolution the suggested model inspires the generalization of peer production to all branches of production, which effectively means the end of capitalism. This in its turn requires the transformation of land and major technological infrastructure into commons that necessitates abolishing the private ownership over them. This, in its turn requires social revolutions that must ultimately overcome the state and its violence and abolishes them.

Such revolutions cannot arrive out of their own accord. They can only be the product of social movements. The revolutionary peer producing cooperative movement can be a vital component of these movements. The major differences between revolutionary cooperatives from those proposed by Bauwens \& Kostakis are two. First, they are consciously organised components of the struggle for reforms and revolution described above. In this sense they are politico-productive units. Second, they reduce their interaction with markets to the absolute necessary minimums. Bauwens \& Kostakis' cooperatives aim at defeating capitalism on its own ground namely the market, keeping categories of value, surplus-value, profit, capital, etc. But, as argued this is doomed to failure.

\footnotetext{
3 The movement of landless in Brazil is a good example of such an exodus, though I am not shore whether this move-
} ment embraces the idea of cooperatives, let alone peer producing ones. 
Bauwens \& Kostaki's economistic project brackets the role of social-class struggle. No mode of production has ever been transformed into another one without decisive role of class struggle in this transformation. The transformation of feudalism into capitalism was not merely a result of the expansion of the capitalist forms of production and commerce. It was also a product of an epoch making multi-faceted cultural revolution, which started with the Renaissance and fully blossomed in the Enlightenment, on the one hand, and a series of political revolutions that started with the English revolution and continued through French revolution, and the European Revolutions of 1848. As a matter of fact, and despite the socialist orientation of some of its slogans, the anti-colonial movement paved the way for the final expansion of capitalism into all corners of the globe by removing the remnants of feudalism.

The transformation of capitalism into peer production cannot be otherwise. It also requires concomitant revolutions in the realms of production, culture and politics. The cooperatives that I propose can only be a link in these revolutions.

The building of these cooperatives requires an exodus from cities to the countryside and the appropriation of land and its transformation into commons on which cooperatives will be built. Perhaps the first waves of such exodus will, though not exclusively consists of the urban "precariat". This is already happening in some parts of the world: the most prominent example of which is the landless movement in Brazil that mainly consists of the urban precariat. Cooperatives will offer them better living conditions: more spacious housing, better and healthier food, better access to culture, health care and education. This, however, does not exclude the participation of the urban dwellers in cooperatives. Of course, landowners will not give their lands out freely to cooperatives, land must be occupied (confiscated). The exodus from cities is in the benefit of urban proletariat too. As we know capitalism uses precariat as a reserve army of labour to cut wages on the hand and impose the so-called "flexible accumulation" which is the worse face of the arbitrary rule of capital, on the other. The exodus will deprive capital from this weapon forcing it to make major concession to urban proletariat in both wages and conditions of work. The exodus will also ease up pressures on housing, education and health services THAT will reduce their prices. Therefore, such an exodus will win the support the urban population. In this way THE cooperative movement is not only involved in transforming land and knowledge into commons and thereby abolishing ground rent and knowledge rent but also bolsters the urban struggles, including that of the urban proletariat.

The cooperative movement must simultaneously instigate a broader exodus of the proletariat and skilled workers, nurses, doctors, engineers, etc. from the capitalist sector. Massive exoduses of this type will push capitalism towards a final crises by increasing dramatically wages and reducing the average rate of profit.

Faced with a global crisis of capitalism that provokes protests everywhere the revolutionary movement must abolish the state and transform the rest of means of productions into commons.

\section{References}

Bauwens, Michel and Vasilis Kostakis. 2014. From the Communism of Capital to Capital for the Commons: Towards an Open Co-operativism. tripleC: Communication, Capitalism \& Criitque 12 (1): 356-361.

Harvey, David. 1982. The Limits to Capital. Oxford: Basil Blackwell.

Harvey, David. 2004. The New Imperialism. Oxford: Oxford UP.

Harvey, David. 2012. Rebel Cities. New York \& London: Verso.

Kleiner, Dmitry. The Telecommunist Manifesto. Amsterdam: Network Cultures.

Marx, Karl. 1976. Capital Vol. I. London: Penguin Books.

Marx, Karl. 1981. Capital Vol. 3. London: Penguin Books.

Mauss, Marcel. 1925/ 1954. The Gift: Forms and Functions of Exchange in Archaic Societies. I. Connison. trans. London: Routledge \& Kegal Paul.

Meretz, Stefan. 2014. Socialist Licenses? A Rejoinder to Michel Bauwens and Vasilis Kostakis. tripleC: Communication, Capitalism \& Critique 12 (1): 362-365.

Maechelbergh, Marianne. 2009. The Will of the Many. London: Pluto Press. 
Rigi, Jakob. Peer Production and Marxian Communism: Contours of a New Emerging Mode of Production. Capital \& Class 37 (3): 397-416.

Rigi, Jakob and Robert Prey. Value, Rent and the Political Economy of Facebook. Forthcoming. The Information Society.

Sahlins, Marshall. 1974. Stone Age Economics. Chicago: Aldine Transaction.

Teixeira, Rorigo Alves and Tomas Nielson Rotta. 2012. Valueless knowledge-Commodities and Financialization: Financial and productive Dimensions of Capital Autonomization. Radical Political Economics 44 (4): 448-467.

\section{About the Author}

Jakob Rigi is an associate professor at Central European Univeristy's Department of Sociology and Social Anthropology. His fields of research include: Sovereignty (state, war, law, coercion, spectacle, patronage, citizenship, ethnicity/nationalism/religion); Market (Neo-liberalism, exchange, money, consumption, urban networks, and kinship); Globalization (cultural flows, migration, cultural diversification/complexity); Social stratification (Class, disposition, sex work); Marx \& Foucault (value \& biopower). Sovereignty (state, war, law, coercion, spectacle, patronage, citizenship, ethnicity/nationalism/religion); Market (Neo-liberalism, exchange, money, consumption, urban networks, and kinship); Globalization (cultural flows, migration, cultural diversification/complexity); Social stratification (Class, disposition, sex work); Marx \& Foucault (value \& bio-power).

http://people.ceu.hu/jakob_rigi 